Ann. Biol. anim. Bioch. Biophys., 1968, 8 (2), 235-247.

\title{
GALACTOKINETIC RESPONSES TO OXYTOCIN AND OTHER SOLUTIONS IN THE COW
}

\author{
M. MORAG (1), T.-K. GRIFFIN ( ${ }^{(2)}$ \\ (1) Negev Institute of Arid Zone Research, Beersheva (Israel) \\ (2) National Institute for Research in Dairying, Shinfield (England)
}

\section{SOMMAIRE}

Chez la Vache, l'éjection provoquée par l'injection intraveineuse de différentes solutions, est appréciée par la mesure du lait résiduel évacué de la glande mammaire. Les solutions injectées sont détaillées sur le tableau 2. L expérience porte sur 24 animaux de race Frisonne.

Le schéma expérimental permet de juger de l'efficacité de chaque injection, après des intervalles de traite de 8 heures et de 16 heures.

L'analyse des résultats montre :

$I^{\circ}$ que l'importance de l'éjection est la même pour la gamme des doses d'ocytocine injectée;

$2^{0}$ que les injections intraveineuses de solutions de chlorure de sodium à différentes concentrations, ainsi que de placebo provoquent une éjection de lait dont l'importance est d'environ $60 \mathrm{p}$. I00 de celle obtenue après injection d'ocytocine;

$3^{\circ}$ que l'injection répétée d'ocytocine semble inhiber l'éjection naturelle.

Les auteurs suggèrent, en conclusion, que le lait résiduel pourrait être extrait par des doses d'ocyto. cine plus faibles que celles généralement utilisées.

\section{INTRODUCTION}

Reviewing the reports of investigations into the galactokinetic dose response to oxytocin in domestic animals, MoRAG and Fox (Ig66) concluded that the quantitative dose response had not yet been adequately described. The investigation of the minimal effective dose necessary for complete udder evacuation in the cow is important in view of the galactopoeitic role of oxytocin demonstrated in that animal (MORAG, I967). It is no less important, because so many experimental designs in secretion rate studies have been based on the oxytocin removal of residual milk. MoRAG and Fox (loc. cit.) went on to describe an experiment in which a double injection of 2.5 i. 1. oxytocin was needed to satisfactorily remove residual milk in the ewe. The same authors further reported that by a weak milk ejection was elicited by intravenous injections of isotonic saline. 
The following experiments were carried out in order to examine the dose response to oxytocin and to various concentrations of saline in terms of the ejection of residual milk in dairy cow, and to test for any interaction between the galactokinetic properties of exogenous oxytocin and the length of the milking interval (and/or the amount of residual milk).

\section{MATERIALS AND METHODS}

The amount of residual milk ejected in response to different levels of oxytocin injection and other solutions were estimated in 24 Friesan heifers. The animals, all in the second month of lactation, were ranked according to previous milk yield. Pairs of animals in the rank order were divided at random to provide two matched yield groups each of 12 animals, which are hereafter referred to as Experiment I and Experiment 2, respectively. Each group was subdivided into 2 blocks on the basis of previous yield and in each block animals were randomly to the treatment sequences of a $6 \times 6$ Latin square. The two group received the treatments concurrently and in all respects other than in the treatments defined in tables 3 and 4 as main plots, they were subject to the same milking, feeding and management procedures. Details of the animals are given in table I. The experiments were carried out using a split-plot Latin square design for which the main plot treatments were as defined in table 2 . The sub-plots were two milking intervals - a $16 \mathrm{~h}$ night and an $8 \mathrm{~h}$ day. The total length of the experiments was 6 days.

$$
6 \text { periods } \times(\mathrm{I} 6 \mathrm{~h}+8 \mathrm{~h})=\mathrm{I} 44 \mathrm{~h}=6 \text { days }
$$

Semi-permanent nylon cannulae were inserted in the external jugular veins of the heifers 4 days prior the experiment. They were held in place with a plaster bandage. The cow were housed in a byre and were held in the stalls by a neck chain above the plaster bandage. They remained in the stalls throughout the experiment.

Milking was carried out using a Gascoigne bucket plant (pulsation rate of $60 / \mathrm{mn}$ at the ratio of $3: \mathrm{I}$ and a vacuum of $37 \mathrm{~cm} \mathrm{Hg}$ ). At milking time the bucket was placed close to the cow by the first operator (cowman) and connected to the vacuum line. The udder was then whashed in warm disinfectant and wiped dry with a disposable paper towel, and the cups were applied immediately. Fore-milking was not practiced. When the flow of milk (as seen through an observation glass) had ceased the cups were removed and the milking lid was fitted to a second bucket. The milk so far obtained was referred to as the naturally ejected fraction. A second operator (injector) approached the cow, placed his left hand on the neck and through a piercible rubber cap on the cannula administered a $2 \mathrm{ml}$ injection (In Experiment $\mathrm{x}$ oxytocin and in Experiment 2 other solutions- 0,5 p.roo chlorbutol was included as a treatment in Experiment 2 as it is the normal preservative for the oxytocin in this series). Immediately following this injection I $\mathrm{ml}$ of citrated normal saline was flushed through the cannula to ensure that all the intended dose contained in Injection $\mathrm{I}$ had entered the blood (the dead volume of the cannula was I ml). For the dummy injection in Experiment 2 (treatment A) the needle of an empty syringe was inserted into the cannula and in this case no flush was given. On the water treatment (E) no citrated flush was given but an additional ml of water was injected. The cups were then replaced by the cowman and when the flow had again ceased they were removed and the buckets changed. The injector then gave the second injection and flush and the cowman replaced the cups, removing them only when the flow had ceased. The responses to the two injections were referred to as Residues 1 and 2 . There was no feeding immediately prior to, or during milking. There were no time lapses between cup removal, the injection and cup replacement, and the planned milking intervals of 8 and $16 \mathrm{~h}$ never varied for any cow by more than 2 minutes. After the third removal the tests were dipped in $5 \mathrm{p}$. Ioo solution of Iosan C. Both the cowman and the injector had worked regularly with the heifers for one month previously. The heifers were accustomed to the presence of the injector and to the handling of their neck for two weeks prior to the experiments. The animals shewed no signs of distress at his approach, or indeed at the introduction of the various solutions into their blood.

The inclusion of a control treatment amongst a series of levels of oxytocin would tend to increase greatly the error term, which because the exprimental design is a Latin square, cannot thus be divided up between the treatments. In order to avoid this situation the series of oxytocin treatments in Experiment I does not contain a control (saline) treatment as did the treatments reported by MORAG 


\section{TABIE I}

Details of experimental animals. All animals were Friesan heifers in the second month of lactation Description détaillée des animaux expérimentaux

(génisses $=$ jeunes vaches Frissonnes au $2^{\mathbf{e}}$ mois de production de lait)

\begin{tabular}{|c|c|}
\hline Cow number & $\begin{array}{c}\text { Mean daily milk yield over previous } \\
\text { week, } g \text {. }\end{array}$ \\
\hline EXPERIMENT 1 & \\
\hline High yielding block & \\
\hline 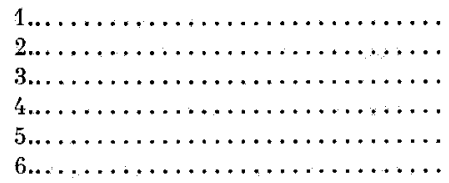 & $\begin{array}{l}14925 \\
17950 \\
14375 \\
16225 \\
14700 \\
15325\end{array}$ \\
\hline Low yielding block & \\
\hline 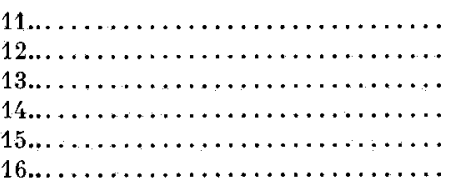 & $\begin{array}{l}13450 \\
12650 \\
11500 \\
13900 \\
12850 \\
12075\end{array}$ \\
\hline $\begin{array}{l}\text { EXPERIMENT } 2 \\
\text { High yielding block }\end{array}$ & \\
\hline $\begin{array}{l}21 \ldots \ldots \\
22 \ldots \ldots \ldots \\
23 \ldots \ldots \ldots \\
24 \ldots \ldots \\
25 \ldots \ldots \\
26 \ldots \ldots\end{array}$ & $\begin{array}{l}14050 \\
17375 \\
15825 \\
14675 \\
14975 \\
14800\end{array}$ \\
\hline Low yielding block & \\
\hline 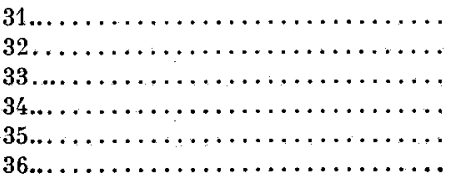 & $\begin{array}{l}12075 \\
13625 \\
12775 \\
12100 \\
13925 \\
13400\end{array}$ \\
\hline
\end{tabular}

All animals were Friesan heifers in the second month of lactation. 


\section{TABLE 2}

Experimental design. All injections were administered in $2 \mathrm{ml}$ volume Détails de l'expérience. Toutes les injections ont été administrés en doses de $2 \mathrm{ml}$

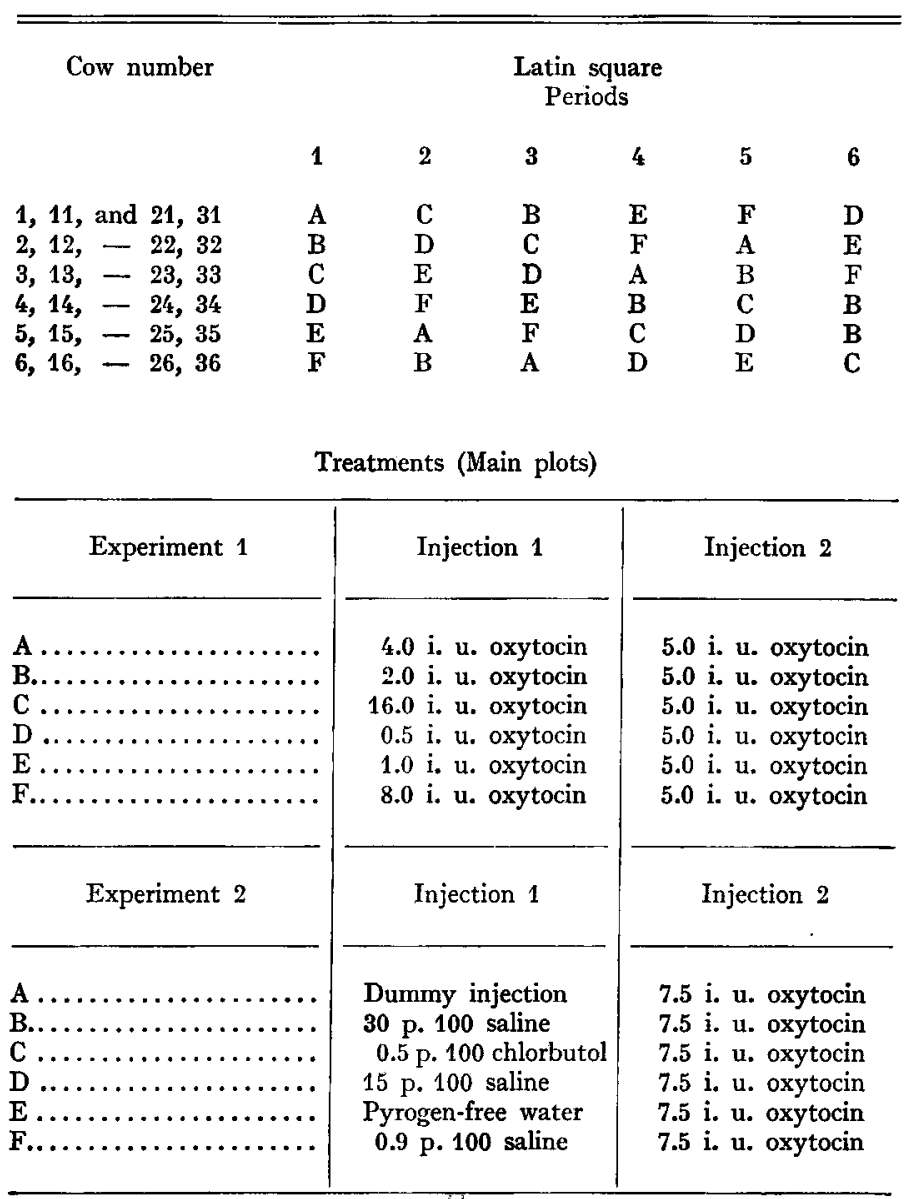

All injections were administered in $2 \mathrm{ml}$ volume. 
and Fox (1966). During preliminary trials on 8 cows a third oxytocin injection of 5 i. u. was given following administration of $(5+5),(5+7 \cdot 5),(2.5+5)$ and $(2.5+7 \cdot 5)$ i. u. respectively and yielded less than $10 \mathrm{ml}$ of milk even when the cows were hand stripped. It was for this reason that only one clearing injection was given in the present experiments (see treatments in table 2).

$7 \mathrm{~kg}$ of hay and $3 \mathrm{I} / 2 \mathrm{~kg}$ of a standard dairy nut were offered daily in two equal meals given after milking to each cow. Water was laid on at each stall. The animals were bedded on wheat straw and cleaned out daily. The byre was brightly illuminated throughout the experiment by day and night. The cows were milked at 0800 and I $600 \mathrm{~h}$.

Milk yields were weighed to the nearest $5 \mathrm{~g}$.

The treatment injections were of an oxytocin extract. This extract (made by Armour Pharmaceuticals Ltd.) is obtained from whole pig pituaries by a process involving the solvent fractionation of the anterior pituitary principle, $0.5 \mathrm{p}$. 100 cholorbutol is added as a preservative. The principle is then diluted to the required strength. The vasopressin content in the batch was $I \mathrm{i}$. $u$. vasopressin to $98 \mathrm{i}$. u. of oxytocin. Contamination with pituitary solutions other than vasopressin was not measurable. The required treatment concentrations were especially prepared in $2 \mathrm{ml}$ aliquots by the manufacturer. All oxytocin injections were flushed through the cannulae with $\mathbf{2} \mathrm{ml}$ of physiological saline. Stringent antiseptic measures were taken with the cannulae and syringes throught the trial.

\section{TREATMENT OF RESULTS}

The yields and secretion rates of milk and fat for the totals and fractions were analysed separately as for a split-plot design, according to the following model :

$$
\begin{aligned}
\mathrm{Y}_{i j k l m} & =\mu+\mathrm{B}_{i}+\mathrm{C}_{i j}+\mathrm{P}_{k}+(\mathrm{BP})_{i k}+\mathrm{T}_{l}+(\mathrm{BT})_{i l}+\varepsilon_{i j k l} \\
& +\mathrm{I}_{m}+(\mathrm{IB})_{m i}+(\mathrm{IC})_{m i j}+(\mathrm{IP})_{m k}+(\mathrm{IBP})_{m i k}+(\mathrm{IT})_{m l} \\
& +(\mathrm{IBT})_{m i l}+\gamma_{i j k l m}
\end{aligned}
$$

When :

\begin{tabular}{|c|c|c|c|}
\hline $\mathrm{C}_{i j}=$ & - & 一 & $j$ th cow in the $i$ th yield block $j=1,2, \ldots 6$ \\
\hline $\mathrm{P}_{k}=$ & - & - & $k$ th period $k=\mathrm{I}, 2, \ldots 6$ \\
\hline $\mathrm{BP})_{i k}=$ & - & 一 & $i$ th yield block in the $k$ th period treatment \\
\hline $\mathrm{T}_{l}=$ & - & $\longrightarrow$ & $l$ th treatment $l=\mathrm{I}, 2, \ldots 6$ \\
\hline$\left(\mathrm{BT}^{\prime}\right)_{i l}=$ & - & $\longrightarrow$ & $i$ th yield block in the $l$ th treatment interval \\
\hline$I_{m}=$ & - & - & $m$ th interval $m=\mathbf{I , 2}$ \\
\hline$(\mathrm{IB})_{m i}=$ & 一 & 一 & $m$ th interval in $i$ th yield block. \\
\hline$(\mathrm{IC})_{m i j}=$ & - & - & $m$ th interval in the $j$ th cow in the $i$ th yield block. \\
\hline$(\mathrm{IC})_{m k}=$ & - & - & $m$ th interval in the $k$ th period. \\
\hline$(\mathrm{ICB})_{m i k}=$ & - & 一 & $\begin{array}{l}m \text { th interval in the } k \text { th period in the } i \text { th yield } \\
\text { block. }\end{array}$ \\
\hline$(\mathrm{IT})_{m l}=$ & - & 一 & $m$ th interval in the $l$ th treatment. \\
\hline$(\mathrm{IBT})_{m i l}=$ & - & - & $\begin{array}{l}m \text { th interval in the } l \text { th treatment in the } i \text { th yield } \\
\text { block. }\end{array}$ \\
\hline
\end{tabular}

$\mu=$ mean yield or rate of a cow in an interval (sub-plot)

$\mathrm{B}_{i}=$ the effect due to the $i$ th yield block $i=\mathrm{I}, 2$

The means for yields and secretion rates of milk and fat with the appropriated sandard errors are given in tables 3 and 4 (Experiment $I$ ) and 5 and 6 (Experiment 2).

The analysis carried out on rates ( $\mathrm{g} / \mathrm{h}$, see Table 3 and 5 ) enables sub-plot $\mathrm{i}$. e. interval comparisons to be tested with a standard error derived from the mean 
M. MORAG, T.-K. GRIFFIN

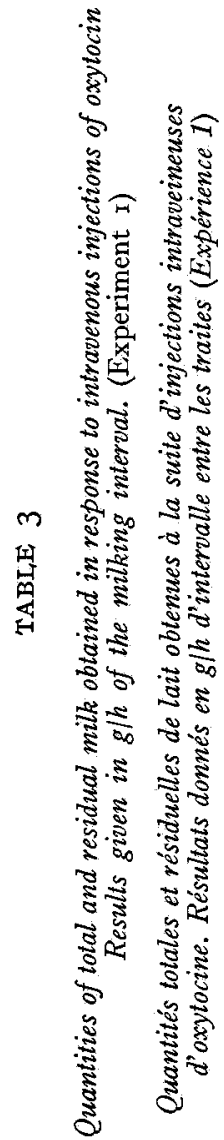

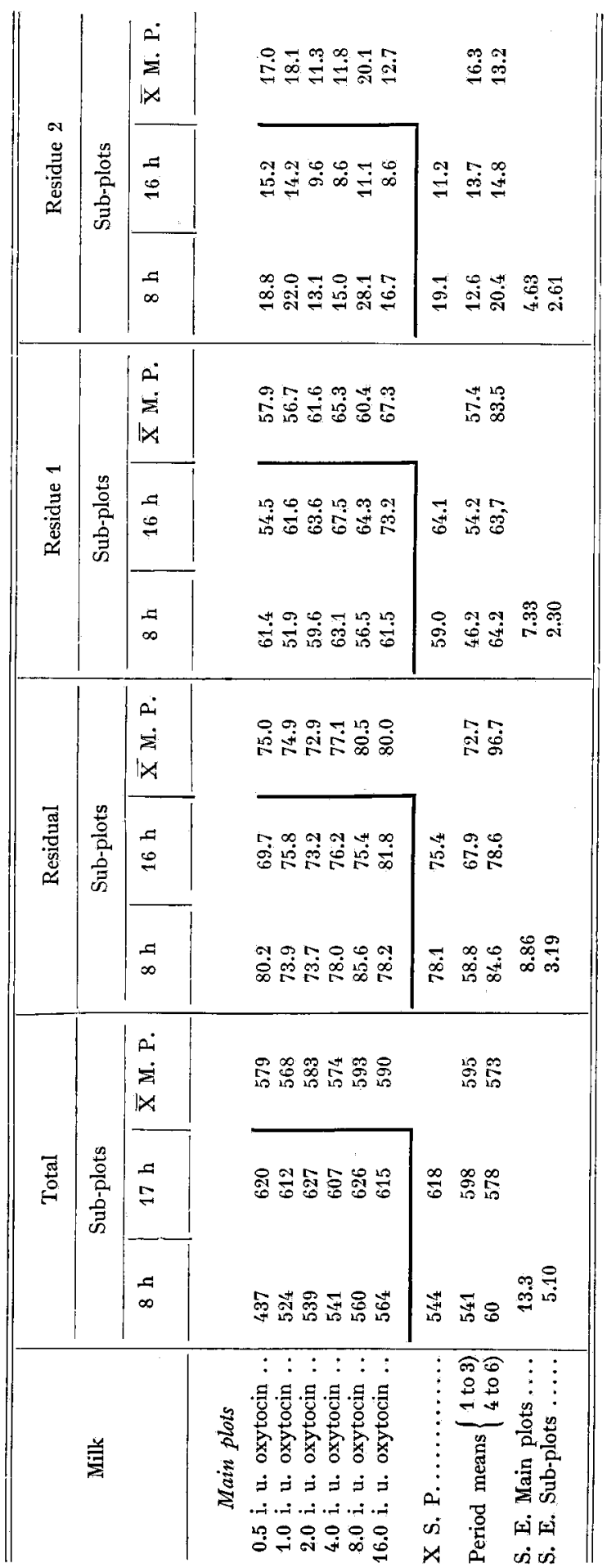




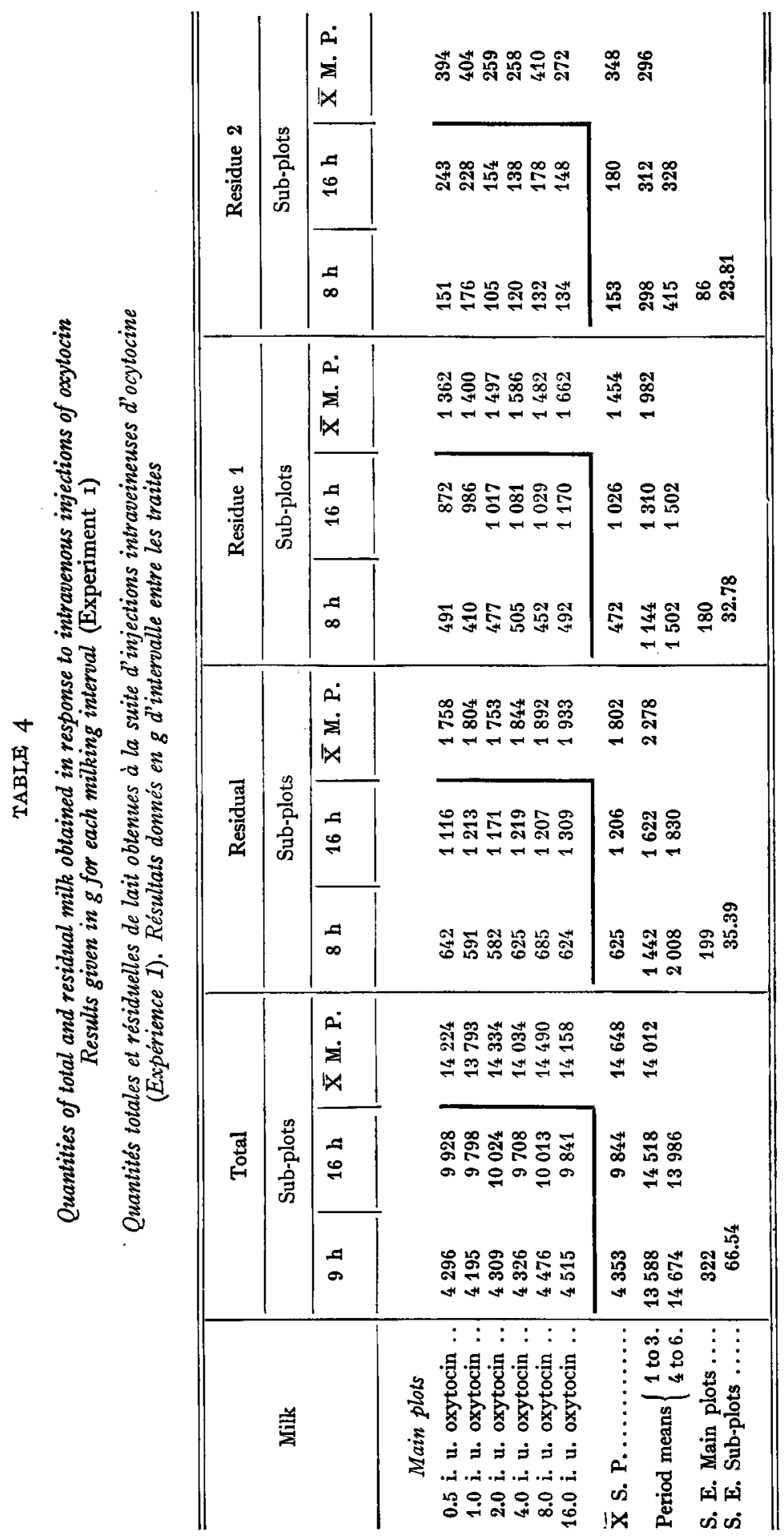


M. MORAG, T.-K. GRIFFIN

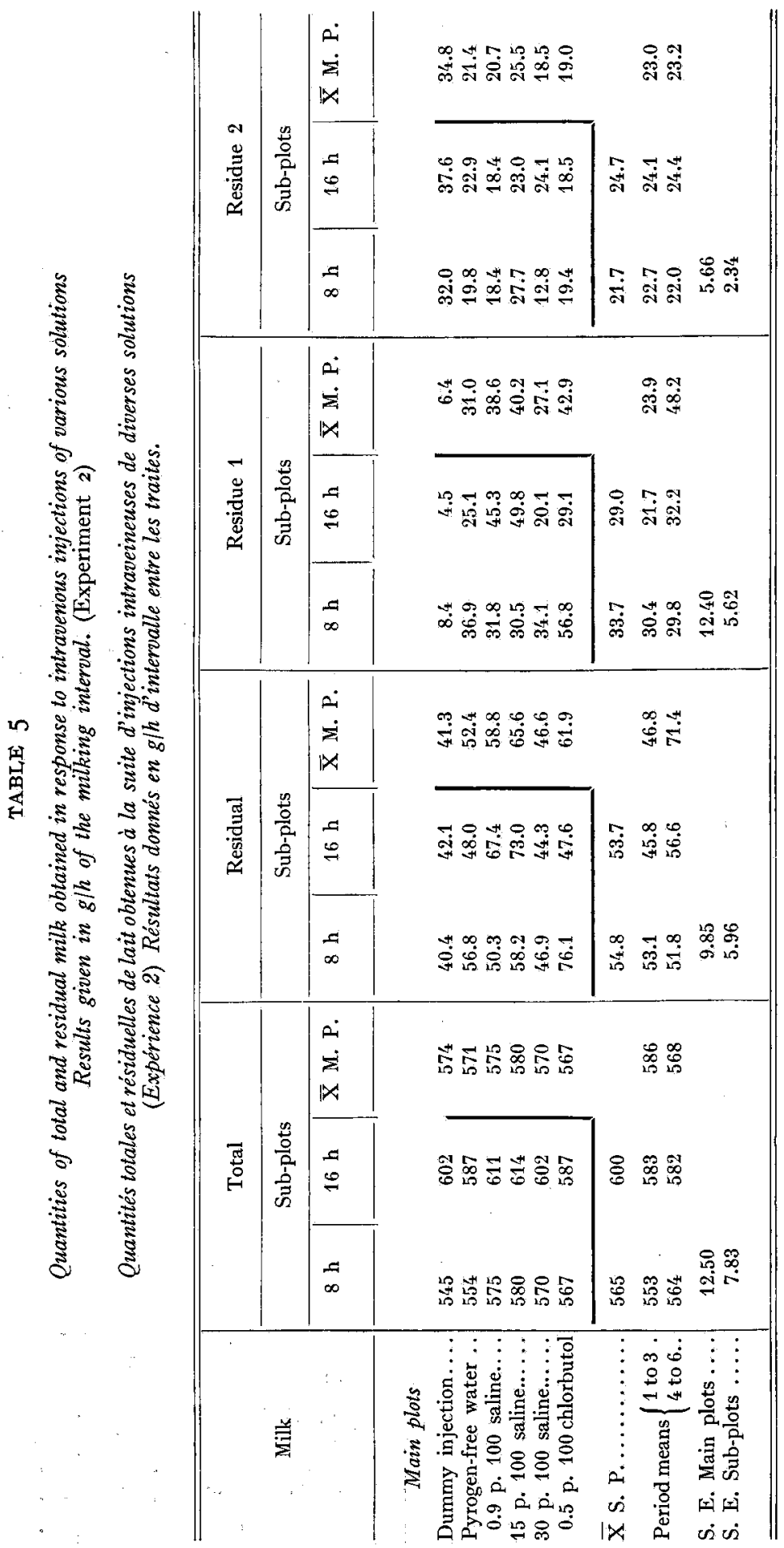




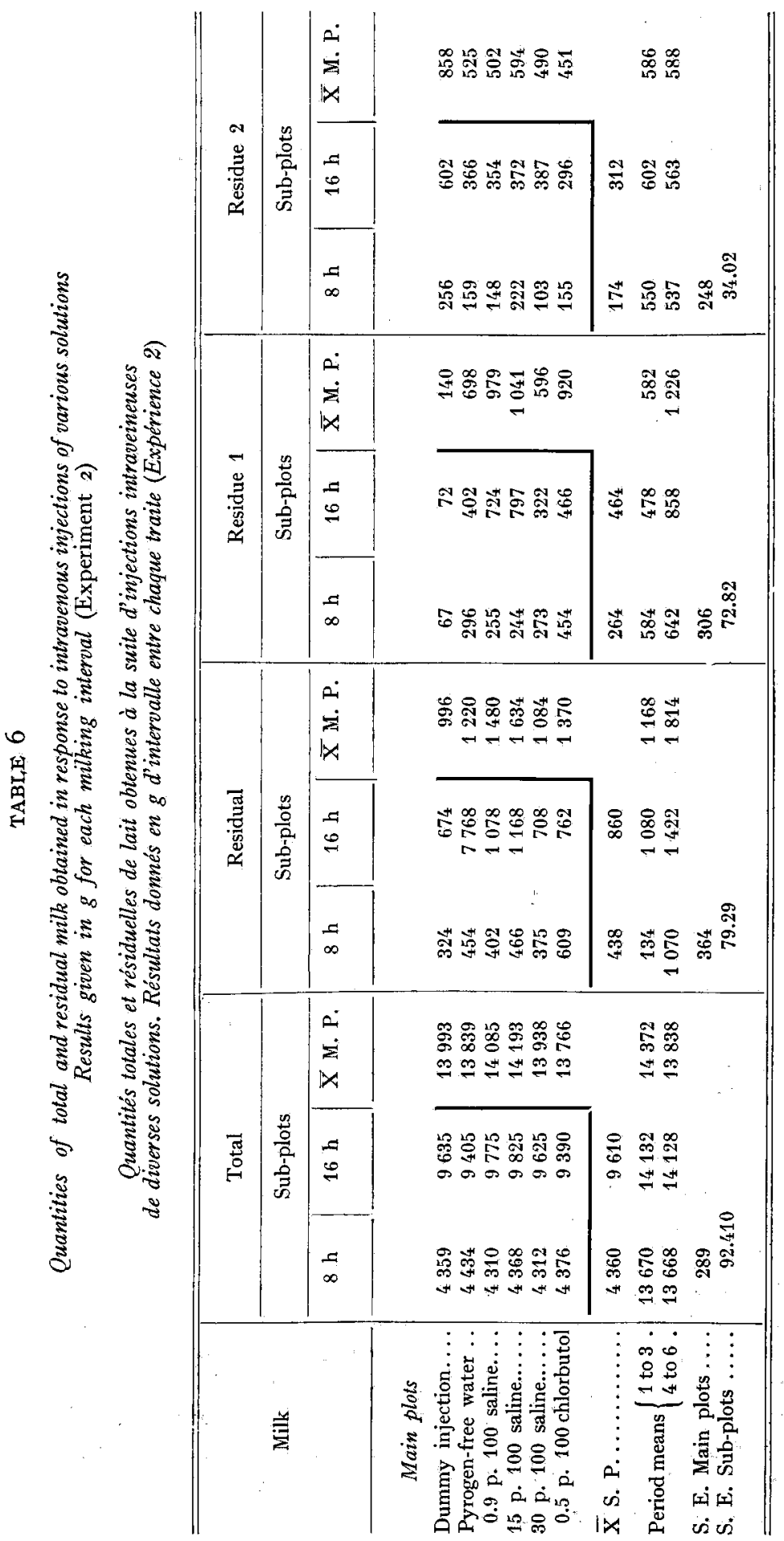


square of error $b$ which is of an appropriate order of magnitude; whilst the analysis carried out on the yields (g, see table 4 and 6) make any consideration of the size of the fractionated portions of milk in the diferent intervals more easy. It is noted that in certain of the analyses error $b$ ) was larger than error $a$ ). In a split-plot design error $b$ ) is characteristically smaller than error $a$ ) (SNEDECoR, I956). It is suggested that in this case the increase in size of error $b$ ) occurred as a result of a negative correlation between periods, and that in future, in order to avoid such a situation, discard intervals should be inserted between the treatment intervals.

It is noted that the means of Residue I measured the actual response to treatment injection, whilst value of Residue 2 was a measure of the galactokinesis due to the treatment plus 5 i. $\mathrm{u}$. in Experiment I and the treatment plus 7.5 i. $\mathrm{u}$. of oxytocin in Experiment 2.

The results of Experiment I shew that there was no significant difference in galactokinetic response over the treated dose range of 0.5 to $16 \mathrm{i}$. u. In Experiment 2 , the salines, water and chlorbutol were found to have some 60 p. Ioo of the galactokinetic activity exhibited by the oxytocin.

\section{DISCUSSION}

\section{Experiment 1}

The apparent linear trend between the oxytocin dose and the quantities of residual milk ejected (Residue I) was non-significant. The values of Residue 2 , as could be expected, appeared to confirm this slight and non-significant trend. The values for Residual and Total milks, however, showed no treatment differences, and thus indicated that the administration of a second clearing injection completely removed any slight main plot trend. The lack of any significant difference in treatment responses and the subsequent removal by the second injection of any slight trends suggests that double injections of very small doses could be effective for the removal of residual milk. In recent secretion rate studies carried out by ScHMIDT (I96I), TUCKER, REECE and MATHER (I96I) and LINNERUD (I964) single injections of Io i u. were used; whilst EILIOTT (I959) used double injections of Io i. u. each in her later experiments. The present data suggest that those workers who used single doses may not have removed all the residual milk (the mean response to the second injection was $332 \mathrm{~g}$ per day), whilst EIIIOTT probably effectively removed all the residua but used a dosage far in excess to that required. The definition of a minimal effective dose is particularly important in view of the evidence of galactopoeitic action by oxytocin demonstrated by DENAMUR (I953), in the goat, and by DENAMUR and MARTINET (I96I), and Morag and Fox (Ig66) in the ewe.

A given dose of oxytocin proved more efficient $(P<0.00 I)$ when the amount of milk in the gland was greater (see mean values for Residue I in two milking intervals). This increase in effectivness of the hormone with an increase in milk volume is similar to that observed by MARTINET (I967). He found that the contractions of mammary strips of guinea pig and rat, measured in vitro, became more pronounced with an increase in milk volume. 
The period means for Residual milk shew a significant increase from the first day to the last ; these values expressed as percentages of Total milk were Io.6, II.2, I2.3, I3.7, I3.8, and I6.2 p. roo. This apparent inhibition of natural ejection and the increase in the relative size of the residual fraction with the administration of exogenous oxytocin and the removal of the residual fraction is in accordance with the observations of SHAW (I942) and of DoDD (I966), the reasons for which are quite obscure. MORAG and Fox (r966) reported a similar phenomenon in ewes, but in that case the increase of the inhibition with treatment was far steeper. In a similar way the period values for Residue I shew a significant increase over the 6 days. This could be due to the same obscure and unexplained phenomenon.

\section{Experiment 2}

The treatment responses as expressed by the values of Residue I would suggest that a definite ejection was produced whenever one of the examined solutions was introduced into the blood. Comparing this response to that obtained in the heifers in Experiment I, the ejection appears to be some $60 \mathrm{p}$. Ioo of that produced in response to the injections of the hormone. (The mean amount of milk ejected by the first injection in Experiment I was I $498 \mathrm{~g}$ whilst the mean of the five treatments in which liquid was introduced into the blood in Experiment 2 was $846 \mathrm{~g}$ (i. e. excluding the dummy injection treatment $A$ ). This response was much larger than the response to isotonic saline reported in the ewe by MORAG and Fox (I966), where the amount of residual milk ejected in response to isotonic saline was only $30 \mathrm{p}$. Ioo of the amount ejected in response to oxytocin. The standard errors for Residue I and 2 are much larger in Experiment 2 than in Experiment $I$; this is because the inclusion of a control treatment has tended to " explode " the error term. One is unable to calculate an error wich would apply only to the other five treatments because of the Latin square design. (See Materials and Methods.) The present data do not suggest that there is any relationship between the concentration of the saline solutions and their galactokinetic activity. Indeed, the response to the water treatment suggests that the ionized radicals of the other solutions are not, in fact, the activators of the ejection. It may be that the liquids have a direct galactokinetic effect on the myoepithelial target tissue and do not act indirectly through the elicitation of an oxytocin release from the pituitary. This hypothesis could possibly be tested by comparing the degree of response to carotid arterial as opposed to jugular venous administration. It is noted that ANDERSSON (I95I), HolidaNd, Cross and SAwYer (I959), and ANdREoli and ChIaUdano (I96I), have described milk ejection in goat, in rabbit, and in woman respectively, in response to hypertonic saline solutions. Evidence of anti-diuretic activity stimulated by hypertonic solutions has been reported by many authors, but the solution were injected into the carotid artery.

It is difficult to see the responses to the dummy injection (Residue I - treatment A) as the result of a further ejection. It is suggested that this amount of milk the quantity of which in absolute terms was similar in both intervals - represents a part of the naturally ejected fraction, which is not removed by the milking routine. It is stressed in the connection that neither machine nor hand stripping were carried out. 


\section{The rate of milk secretion and the changes in the quantity of residual milk}

In both experiments the rate of milk secretion was higher during the $\mathrm{I} 6 \mathrm{~h}$ than during the $8 \mathrm{~h}$ interval. These estimates correspond to the actual amount secreted during the intervals as residual milk was removed at the beginning and at the end of every interval. It could be argued that the difference in secretion rate was due to a preceding interval effect (the $8 \mathrm{~h}$ interval always coming after the $\mathrm{I} 6 \mathrm{~h}$ interval and vice-versa), but from the quantitative estimates of this effect published by EILIOTT (I959) and SCHMIDT (I96I) is would seem that this effect would not account for the significant increase of 12 p. Ioo in Experiment $I$ and of 6 p. roo in Experiment 2 in the rate of milk secretion. There has been no previous communication which has reported an actual secretion rate which was higher during the $\mathrm{I} 6 \mathrm{~h}$ than during the $8 \mathrm{~h}$ interval in the cow.

In both experiments the amount of residual milk after an interval of $\mathrm{I} 6 \mathrm{~h}$ was twice the amount after an interval of $8 \mathrm{~h}$. This confirms the general model proposed by TURNER (I955), in the cow and by SEMJAN (I962), in the sheep, but does not lend support to the model presented by ELIIOTT (I959) in which she described a constant level of residual milk after intervals of 8 to $\mathrm{I} 6 \mathrm{~h}$.

The effectiveness of the small doses of oxytocin in Experiment $I$ and the relatively strong ejection demonstrated by the various liquids in Experiment 2 indicate the necessity of further work in which even lower doses of oxytocin are tested both as first and second (clearing) doses, and in which successive doses of the various liquids are tested (i. e. as first and second doses) for their galactokinetic activity.

Rę̧u pour publication en décembre 1967 .

\section{ACKNOWLEDGEMENTS}

This study was carried out whilst one of us (M. M.) was in receipt of the Huntley and Palmer Researchship. The work was financed by grants from the Miriam Sacher Charitable Trust and the Milk Marketing Board. The specially prepared oxytocin was donated by Mr. W. F. TICEHURST of Armours Pharmaceuticals Ltd. We record our thanks to all concerned. We are likewise grateful to Miss F. J. NUTT and Miss J. Bromley for the statistical analysis. The milking was carried out by Mr. W. DAvies. We would thank Dr F. H. DoDD and Mr. S. Fox for their helpful criticisms at all stages of the work.

\section{SUMMARY}

The galactokinetic dose responses to intravenous administration of oxytocin (0.5-I6.o i. u.) to various strengths of saline, to water and to $0.5 \mathrm{p}$. 100 chlorbutol were measured in terms of ejection of residual milk in the cow. A split-plot Latin square design was used and each injection was tested after an $8 \mathrm{~h}$ and $16 \mathrm{~h}$ interval.

The trial was carried out using 24 Friesan heifers. No significant differences in galactokinetic activity were found to exist aver the tested range of oxytocin. Saline, water and chlorbutol solutions were found to have some $60 \mathrm{p}$. Ioo of the galactokinetic activity shown by oxytocin.

The administration of oxytocin inhibited natural milk ejection. It was suggested that residual milk could be effectively removed by doses smaller than those generally used. 


\section{REFERENCES}

ANderson B., 1951. Some observations on the neuro-hormonal regulation of milk ejection. Acta physiol. scand., 28, I-7.

Andreoli C., ChIAundo G., I961. Milk-ejecting effect of hypertonic saline solution in woman. Gynaecologia, 151, 46r-464.

Chambers G. H., Melville E. V., Hare R. S., Hare K., I945: Regulation of the release of pituition by changes in the osmotic pressure of the plasma. Am. J.'Physiol., 144, 3I 1-320.

Denamur R., I953. Action de doses répétées d'ocytocine sur la sécrétion du lait chez la Chèvre. C.R. Soc. Biol., 147, 88-92.

Denamur R., Martinet J., I96r. Action de l'ocytocine sur la sécrétion du lait de Brebis. Ann. Endocr., 22, 777-78I.

DoDd F. H., 1966. Personal communication.

ELLIOTT G. M., 1959. The effect of milk accumulation in the udder of the dairy cow upon secretion rate: its bearing on certain milking practices. Ph. D. Thesis, Univ. Reading.

Gilman A., Goodman L., I937. The secretory response of the posterior pituitary to the need for water conservation. J. Physial., 90, II3-124.

HARE R. S., Hare K., Phillips D. M., r943. The renal excretion of chloride by the normal and by the diabetes insipidus dog. Am. J. Physiol., 140, 334-348.

Holland R. C., Cross B. A., Sawyer G. H., I959. Effects of intracarotid injections of hypertonic solutions on the neurohypophyseal milk-ejection mechanism. Amer. J. Physiol., 106, 791-795.

LinNERUd A. C., I964. The secretion rate of milk and milk components as effected by the intervals of milking Ph. D, Thesis, Univ. Minnesota.

Martinet J., I967. Personal communication.

MoraG M., I967. A galactopoeitic role for oxytocin in the cow. Life Sci., 6, 1513-15I8.

MoRAG M., Fox S., 1966. Galactokinetic responses to oxytocin in the ewe. Ann. Biol. anim. Bioch. Biophys., 6, 467-478.

ScHMIDT G. H., I96o. Effect of milking intervals on the rate of milk and fat secretion. J. Dairy Sci., 43, 2I3-220.

SemJaN S., I962. Residual milk of sheep. XVI Int. Dairy Congr., 1, r 7-24.

SHaw J. C., I942. The effect of oxytocin on milk and milk fat secretion. J. Dairy Sci., 25, 1051-1055.

SNedecor G. W., 1956. In Statistical Methods 5th Edition. The Iowa State University Press, Ames, Iowa, U.S. A.

Tucker H. A., Reece R. P., Mather R. E., I96I. Udder capacity estimates as effected by rate of milk secretion and intermammary pressure. J. Dairy $S c i ., 44,1725^{-1732}$.

TURNER H. G., I955. Sources of variation in residual milk and fat in dairy cows : their relation to secretion rates and persistancy of lactation. Aust. J. Agric. Res., 6, 514-529.

Verney E. B., 1948. The antidiuretic hormone and the factors which determine its release. Proc. R. Soc., B, 135, 25-106. 